\section{Fact and fiction}

\section{S.A. Barnett}

The Longman Llterary Companion to Science. Edited by Walter Gratzer. Longman: 1989. Pp. 517. £17.95. To be published in the United States by Norton. From Creatlon to Chaos: Classic Writings in Sclence. Edited by Bernard Dixon. Basil Blackwell: 1989. Pp. 280. £15, $\$ 29.95$.

Here are two compendia about aspects of the scientific life. Both, especially Gratzer's, can be read with enjoyment; both are highly misleading.

Gratzer wishes to "explore the incursions of science into literature". Happily, his 216 excerpts (each of which has a brief editorial introduction) are not only from stories and poetry; many are highly readable and informative passages from biography and journalism. Readers should not be deterred by the unrepresentative false start. The first section, "The Laboratory Scene", opens with a series of exposés of "the research supervisor as a monstrous incubus". Supervisors are far more often harrassed than depraved. In default of a quantitative survey of supervision, we need a David Lodge to write a hilarious but authentic novel on the struggles of a supervisor to get her pupils to write up their work, and her final resort to writing the papers herself.

After the supervisor, we have "the research grandee and the array of his vassals". Nobel prizes, and their winners, though rare in real laboratories, loom large in this collection. Only by the fifteenth entry do we reach one of the few fictional descriptions of what research is really like: in Nigel Balchin's A Sort of Traitors, two research assistants patiently but resentfully record many thousands of cultures as showing "slight growth". And, much later, there is a comment on Ernest Rutherford (in Gratzer's words, "probably the greatest experimental physicist of this century"): "he got pleasure not only from the high moments, but also from the hours of what to others would be drudgery, sitting in the dark counting the alpha particle scintillations on the screen". Another rarity is a poet, Louis MacNeice, with his unromantic but not unkind portrait of a scientist who lived by measuring things

And died like a recurring decimal

Run off the page, refusing to be curtailed;

Died as they say in harness, still believing

In science, reason, progress.

A book such as this could hardly dwell at length on quiet people and non-events. It is appropriate that we should be horrified by the effects of anti-semitism in
Poland, or of McCarthyism in the United States; that we should be frightened by an account of accidental death due to radiation; and sickened by the outcome of mindless bombing in the Second World War. In contrast, we may applaud the case of the brilliant but wayward student, admitted to a course of study though without qualifications. And we may enjoy passages from those masters of satire, Jonathan Swift and Samuel Butler, or turn for light relief to stories of the great in disconcerting situations - for instance, Albert Einstein trying to steal tobacco from Niels Bohr.

Gratzer's exertions do not seem to have been entirely a labour of love: he comes over as ambivalent towards scientists. He quotes a tribute by a classical scholar, Maurice Bowra, who said that scientists were treacherous allies on committees because "they are apt to change their minds in response to arguments", but he immediately qualifies it by reference to scientists' "passions" and, in a section on "Discovery", he states that "emulation and jealousy among scientists have [today] become sanctified as the motives that drive scientists ever onwards" Here, perhaps, is another hypothesis in need of a survey.

$\mathrm{He}$ finishes, as he begins, with bathos: the last section, "The Pathology of Science", contains a mixed bag of accounts of fraud and plagiarism by scientists and bogus science by illusionists, with only one (fictional) example of commercial skulduggery. Gratzer could have acknowledged that his patchwork is far from a representational portrait of science by ending with a remark by the physicist, Jeremy Bernstein, quoted on p. 151: "I pity the historians of science and others who are attempting to put together a reliable history [of science]; all you have to do, you may think, is ask the participants for their accounts of what happened. But such stories can be woefully misleading".

Bernard Dixon, too, is concerned with literature: by publishing his collection, he hopes to "demolish the well-worn cliché that scientists, by their nature and training, cannot write", although his medley of excerpts includes many by science writers (and even a rather dim limerick by Arthur Koestler). Most of his preface is directed at encouraging young scientists to write well. He warns adolescents against trying to imitate "models of unattainable excellence", and says that instead they should learn by analysing bad writing and read great prose for pleasure so that "lessons of style ... sink in by subconscious osmosis". But he ignores the principal, perhaps the only, effective method of developing order, clarity and conciseness, which is to practise and to subject one's attempts to criticism.

Dixon also tells us that his book's "sole raison d'être is to provide pleasure for the reader". Except that they are said to be selected "solely on the basis of literary quality" the writings are unfortunately presented without editorial comment. Yet the pleasure and instruction one derives from reading are due to the combined effects, often inextricable, of style, content and context.

After the confusing preface, a reader should not be surprised to find a rather uneven selection. The passages are 
arranged alphabetically, hence are randomized. Six items are in verse. Of 69 prose excerpts, 18 are fragments that convey little and hardly do justice to their authors. They could well have been replaced by longer passages from writers such as Bertrand Russell and Joseph Needham who are not represented.

Among the remainder are several which, I hope, will send readers back to the originals. Here is Haldane, in 1932, on the evolutionary process: "In the first place, it is very beautiful. In that beauty is an element of tragedy. ... . In an evolutionary line rising from simplicity to complexity, then often falling back to an apprarently primitive condition before its end, we perceive an artistic unity similar to that of a fugue". And here is Peter Medawar (1960), another polymath, writing less agreeably on the same subject: "It is a profound truth ... that nature does not know best; that genetical evolution, if we choose to look at it liverishly instead of with fatuous good humour, is a story of waste, makeshift, compromise and blunder".

Human evolution appears in questions asked by A.R. Wallace (1875) in an unfamiliar idiom: "whether we compare the savage with the higher developments of man, or with the brutes around him, we are alike driven to the conclusion that in his large and well developed brain he possesses an organ quite disproportionate to his actual requirements - an organ that seems prepared in advance, only to be fully utilized as he progresses in civilization".

Wallace also appears in an extract from Darwin's Autobiography of 1876 , where the author scolds himself for overlooking (in the 1840s) an important problem "the tendency in organic lines descended from the same stock to diverge in character as they become modified. The solution, as I believe, is that the modified offspring of all dominant and increasing forms tend to become adapted to many and highly diversified places in the economy of nature". An alternative autobiographical model is provided by Otto Frisch (1979), who describes a visit to his aunt, Lise Meitner, in exile in Sweden, which led to a major discovery in atomic physics. Or one may turn to H.G. Wells (1934) on his unsuccessful attempts, as a hamfisted student in the $1890 \mathrm{~s}$, to make apparatus, and his all too successful campaign to burlesque his professor; or to Miriam Rothschild writing cheerfully, in 1987 , on having seven years of work destroyed by a Nazi bomb.

The reader may also compare T.H. Huxley's famous account of a piece of chalk (1868) with Primo Levi's still more readable story of a carbon atom (1984). Rachel Carson's brilliant Silent Spring (1962) may be contrasted with E.J.H. Corner's lucid Life of Plants (1964). A problem outside the natural sciences is presented by S.J. Gould (1984) in a discussion of Adam's navel - an enigma indeed, for Adam was created, not born. These and other passages show that a few people with scientific training write well, even superbly. Classified and put briefly in context, they could have made a treasury to be read both for pleasure and for instruction. I especially emphasize the second purpose, for such a volume is needed to help in remedying a lamentable state of affairs - that most scientists still write badly.

S.A. Barnett is Emeritus Professor of Zoology in the Australian National University, Box 4 , GPO, Canberra, ACT 2601, Australia.

\section{Blaming biology?}

Daniel J. Kevles

Dangerous Dlagnostics: The Soclal Power of Blological Information. By Dorothy Nelkin and Laurence Tancredi. Basic Books: 1989. Pp. 207. \$18.95.

BIOMEDICAL research, especially in genetics and the neurosciences, has been generating an increasing range of new diagnostic methods and machines. Medical genetics can specify several thousand single-gene diseases and disorders, while magnetic resonance imaging, PET-scan and other techniques can detect numerous abnormalities in the brain. The new diagnostics reaches beyond the detection of physical maladies such as Tay-Sachs disease or brain tumours to identify tendencies to particular types of behaviour or mentality, drawing on recent scientific research that has found, for example, genetic sources for schizophrenia or brain lesions linked to learning disabilities. To be sure, the growth in diagnostic power has far outpaced therapeutic capacity. But never mind: diagnosis has its uses independent of cure. Diagnosis produces information about individuals that can assist life decisions they make for themselves - or that are made for them by others.

Genetic assessments have for some years figured in clinical settings, typically permitting prospective parents to learn the risk of conceiving a child that suffers from a genetic disease or assisting the physician in identifying the physical cause of a patient's malady. However, the broadening powers of neurophysiological and genetic tests are making them evermore appealing as devices to screen individuals with benefit, it is said enthusiastically, not only to themselves but to society. The National Institute of Mental Health has expressed a commonplace expectation: "Pre-symptomatic detection of psychiatric disease will be routine. Subjects at risk for alcoholism, schizophrenia, or depression may be identifiable well before the onset of clinical symptoms" (pp. 5-6). Families and physicians will thus be better prepared to take preventive action or apply therapeutic measures.

Diagnosis is similarly touted for use elsewhere in society. In the schools, it will assist teachers in dealing with troublesome children; in the courts, help specify the degree of a defendant's mental capacity; in the insurance world, aid in the determination of a client's health risk and, hence, premiums; and in the workplace, identify the propensity of workers to fall ill in response to, say, chemicals. According to the Journal of Occupational Medicine, diagnostic screening makes good business sense because it can "lead to reduced absenteeism, increased productivity, and decreased expenditures for workers' compensation and group health insurance" (p. 90).

In Dangerous Diagnostics, a critical survey and analysis of the diagnostic trend, Nelkin and Tancredi allow that the testing may indeed be valuable - as is, for example, DNA fingerprinting in the courts - but they argue, with arresting persuasiveness, that much of it is alarming. Nelkin, a sociologist at New York University, is an authority on the affairs of science and society. Tancredi directs the Health Law Program at the University of Texas Health Science Center in Houston. Their respective talents and expertise are advantageously joined in this book, which they wrote to stimulate debate about "the potential uses and abuses" of the emerging biological tests and as a kind of technology assessment addressed to their inherent social and political implications (p.ix).

Among the strengths of Nelkin and Tancredi's treatment is their insistence that the danger in diagnostics arises not so much in any evil intent as in the way that institutional contexts, and the values inherent in them, encourage the assessments to be used - and abused. A rapidly growing diagnostics industry presses the tests upon the world ("The future lies in genetic tendencies", an industrial biotechnologist has declared- p. 5). In the courts, reliance on 'hard' biological evidence of mental condition may improve the efficiency and reduce the costs of the judicial process; it can also exclude traditional psychiatric testimony that places the mental state of defendants, to their advantage, in a broader setting. Diagnostic screening in the workplace may improve productivity and decrease liability; it also shifts responsibility for workplace hazards from the company to the employee. Screening may better reveal an individual's risk of disease; but it enables health-care providers and 